\title{
I am the Way, the Truth and the Life (John 14.6)
}

\author{
Ma. Lucia C. Natividad
}

\begin{abstract}
Jesus proclaims "I am the way, the truth and the life; no one comes to the Father but through me" (John 14.6). He is "the way" because he is the revealer of the Father. He is the only Begotten Son of the Father who comes from the bosom of the Father. Jesus is "the way" to the Father because he is "the truth," since one can come to the knowledge of the Father only through Jesus who has manifested the intimate union between the Father and the Son. Hence, to know and to see Jesus is to know and to see the Father. He is "the way" because he is "the life" for he lives in the Father and the Father dwells in him. The revelation of Jesus is the truth about God and also about what it means to be human. Jesus is the perfect expression of divine love and calls his disciples to pattern their lives on God's love that is manifested in him.
\end{abstract}

KEYWORDS: I am, Jesus, Life, Revelation, Way, Truth, Discipleship

The core of John's gospel revolves around the theme of revelation. Everything in the gospel is organized and centered on Jesus, the perfect revelation. Jesus' role is defined in the gospels as the one who reveals the Father. This leading idea in the gospel of John is established in the Prologue (John 1.1-18) and developed in the entire gospel. This thought expresses the revelation of the divine commitment involved in the sending of the Son. Jesus is the Begotten Son who comes from the Father and sent by the Father to manifest and share the life of the Father. He lives among people and lays down his life for his friends and draws them through faith and love into the divine communion of love. Jesus Christ is the perfect revealer of divine life for he is the sacrament of the divine life, the place where revelation is concentrated, the temple of God's presence and the presence of God in the world.

God, the source of being, freedom and the possibility of every creature, is utterly beyond humanity and may appear as a remote and invisible God. However, through the incarnation and Jesus' life, passion, death 
and resurrection the transcendent God who is infinitely beyond all is immediately and creatively present. He is not the distant and inaccessible Being beyond being, but the God who is ever-present in all and in the world. Jesus expressed, "If a man loves me, he will keep my word and the Father will love him. And we will come to him and make our abode in him" (John 14.23). He is the God who became man, who personally communicates himself to humanity by divine indwelling. This is the new and more intimate presence of the divine life in the hearts of all through the indwelling presence of the divine Spirit. Therefore, God's Spirit, which abides in humans, surpasses God's presence in creation. God's enduring presence in the depths of the person involves an intimate and personal relationship. "The Spirit of truth whom the world cannot accept, since it neither sees him nor recognizes him; but you can recognize him because he remains with you and will be within you" (John 14.17).

Jesus Christ manifested God who is both transcendent yet so near. The Word of God has come forth out of His mystery and became flesh. He is the one through whom the divine life can be known. Therefore, although the mystery that is hidden from all eternity is now unveiled in Jesus Christ, still God never ceases to be a mystery. There is so much more to know about the divine mystery.

As the supreme revealer of God, Jesus exercised his role in all the ways that are consistent with his Incarnation, through his full presence and manifestation in his teachings and signs and wonders, through his words and deeds culminating in his passion, death and resurrection. God reveals himself in Jesus Christ who is the Word of God made flesh in order to communicate the divine life and the meaning of human life.

The economy of revelation is realized by deeds and words, which are intrinsically bound up with each other. The works performed by God in the history of salvation show forth and bear out the doctrine and realities signified by the words; the words for their part, proclaim the works, and bring to light the mystery they contain. (Dei Verbum 2)

A common revelatory word of Jesus in the gospel of John is the "I am" revelatory formula that is followed by a nominal predicate. ${ }^{1}$ This paper attempts to understand Jesus' revelation through an investigation of one of his "I am" pronouncements, "I am the way, the truth and the life; no one comes to the Father but through me" (John 14.6).

${ }^{1}$ The "I am" revelatory formulae in John are found in $6.35,51 ; 8.12 ; 10.7,9,11,14 ; 11.25$; 14.6 and $15.1-5$. 
Various explanations and interpretations have been given for this particular "I am" saying. The Mandean and Heremetic writings proposed Gnostic dualism. It was generally believed that "the truth" was exclusively in the sphere of divinity and in the final term of the journey while "the way" was the route to divinity.

Another interpretation was that "life" or "life and truth" together were understood as the end to be attained through the mediation of Jesus who is "the way." Hence, the three terms were interpreted as a progressive movement from one leading to the other. It was formulated either as, "by the way and the truth, one approaches the life," or "by the way, one attains truth and the life." Special value was given to the second and the third predicate and hence these were seen as the goals to be reached. This interpretation was a result of Platonism, wherein the truth and life were perceived to be eschatologically divine realities. Augustine, Clement of Alexandria and Origen supported this kind of thinking. They related "truth" and "life" to the Logos in his preexistence. They thought of Christ as the intellect or thought of God and identified him with truth as Logos (De la Potterie 59).

Most of the Greek Fathers, as well as Ambrose and Leo the Great (Leo I), understood "the way" and "the truth" as leading to eternal life in heaven. Maldonatus modified this by giving "the truth" the value of an adjective. This means that "I am the true way that leads to life." The primacy was given to "the life" which is the goal of "the way." However, many modern scholars such as De la Potterie, Bengel, B. Weiss, Schlatter, Strathmann, W. Michaelis, Tillman and Van den Bussche advocate the view wherein "the way" is the primary predicate, and "the truth" and "the life" are just explanations of "the way." Jesus is "the way" because he is "the truth" and "the life" (De la Potterie 59).

The various interpretations of John 14.6 can be summed up in two categories. The first explanation is that "the way" is directed toward a goal that is "the truth" and "the life." The other explanation is that "the way" is the primary term and "the truth" and "the life" explain "the way."

Using these varied interpretations on the verse, this paper attempts to answer the question: What is Jesus saying in his pronouncement: "I am the way, the truth and the life?" This paper presents an in-depth study of John 14.6 in three parts. The first part explains the verse's three terms, namely "the way," "the truth," and "the life," and their relationship to each other. The second part explains the verse through an in-depth study of the verse's structure. The first sentence is stated positively while the last sentence is expressed negatively. This structure sheds light on Jesus' 
proclamation that he is the way, the truth and the life. The third part discusses the relationship of John 14.6 to parallel verses in John's Prologue. This paper concludes with the theological significance of Jesus the perfect revealer for the life of his disciples.

\section{I. "I am the way, the truth and the life" (John 14.6)}

The Johannine phrase ego eimi or the "I am" is a revelatory formula. These two words taken as such assert the oneness of the Father and the Son. "Only as the Son, the logos theou (the Word of God), could such an assertion be made." Paul Minear contends that the "use of the ego eimi (I am) absolutely relates Jesus to God. ${ }^{2}$ However, when a predicate is added to Jesus' pronouncement, Jesus relates to human life" (486). Jesus' assertion that he is "the way, the truth and the life" reflects and defines his relationship with humanity.

\section{The Way}

The term "the way" has a moral connotation in the Old Testament. The Jewish notion of Halakhah was based on the moral theme of walking in the way marked by the Law of God (Forestell 34-35). "Be careful, therefore, to do as the Lord, your God, has commanded you, not turning aside to the right or to the left, but following exactly the way prescribed for you by the Lord, your God, that you may live and prosper, and may have long life in the land which you are to occupy" (Deut. 5.32-33).

The "way" and "truth" are presented as parallel texts in the Old Testament: "Teach me, Lord, your way, that I may walk in your truth" (Ps. 86.11a). This expression signifies a manner of living which ought to be in conformity to the law or the right way of living. The way is the way to the knowledge of God and the knowledge God wants for the people. In these Old Testament texts the "way to truth" does not appear in the manner of the Gnostic writings wherein the truth comes from the transcendent sphere and is the goal of the journey. Hence, "the way" is the way of the truth.

"Way of life" in the Old Testament signifies conformity to the moral law: "Way of life are reproofs of discipline" (Prov. 6.23). The "way of life"

${ }^{2}$ When Moses was called, he asked for God's name, should the Israelites ask him. The Lord identified Himself to Moses. "I am whom am." Then He added, "This is what you shall tell the Israelites I AM sent me to you." God spoke further to Moses, "Thus shall you say to the Israelites: The Lord, the God of your fathers, the God of Abraham, the God of Isaac, the God of Jacob, has sent me to you. This is my name forever. This is my title for all generations" (Exod. 3.14-15). 
is revealed by God. The psalmist pleads to God, "You will show me the path to life, abounding joy in your presence, the delight at your right hand forever" (Ps 16.11). This text "comes close to combining John's three notions of way, truth and life," according to Raymond Brown (628). The instructions on the "way of life" have an eschatological overtone for it leads from death to life or from Sheol to the presence of God: "The path of life leads the prudent man upward, that he may avoid the nether world below" (Prov. 15.24). The Old Testament usage of "the truth" and "the life" are closely associated with the moral implications of "the way."

In the New Testament, the phrase "new way" was a title associated with the followers of Christ in the first century. ${ }^{3}$ This new way was a selfdesignation for Christian discipleship. It expresses the idea that Christian discipleship is the culmination of God's revelation to the human person and the person's relationship to God. The "new way" also means "the way that prepared for the ultimate coming of Christ, a way of life commanded by Jesus and motivated by the Spirit" (Brown 629).

In John 14.6, when Jesus announced that he was "the way" he was not presenting himself as a moral leader nor as a moral guide for Jesus' disciples to follow, as in Hebrews 2.10. ${ }^{4}$ The evangelist did not put stress on the moral aspect of "the way" as found in the Old Testament thought of "the way of truth" or "the way of life" but rather presents Jesus as the revelation of the Father and as such is "the way." He is the way by being the truth and the life.

John 14.6 belongs to Jesus' Farewell Discourse (John 13.31-17.26). John 13.31-38 is the context of the Farewell Discourse which centers on the meaning of Jesus' departure from the world. The introduction of the farewell discourse announces that Jesus will soon leave his disciples (John 13.33). Realizing this impending departure, Jesus gives his disciples a new commandment. "Love one another. Just as I have loved you, you should love one another. By this everyone will know that you are my disciples, if you have love for one another" (John 13.34-35). This provokes Peter's question: "Lord where are you going?" (John 13.36a). Jesus answered with stern directness, "Where I am going, you cannot follow me now, though you will follow later" (John 13.36b). Though the reply is qualified by the important promise that "later on" Peter will be able to follow.

${ }^{3}$ See Acts 9.2; 19.9, 23; 22.4; 24.14, 22.

4"For it was fitting that he, for whom and through whom all things exist, in bringing many children to glory, should make the leader to their salvation perfect through suffering" (Heb. 2.10). 
The words "to go" in Peter's question are substituted by Jesus' answer "to follow" which hints at a brief development of the idea of discipleship or following Jesus. Following Jesus involves two meanings. The first one entails taking the same path of self-giving love Jesus manifested in his public ministry and especially on the cross. Following Jesus means to pass through death to gain new life. Peter responded by asking Jesus, "Master, why can't I follow you now? I will lay down my life for you" (John 13.37). Jesus asked Peter, "Will you lay down your life for me?" (John 13.38a). Peter misunderstood the Lord. He was thinking of human journeys into some dangerous place and time. Jesus knew well that at the moment of his trial Peter would deny him three times and deny his identity as Jesus' disciple: "Will you lay down your life for me? Amen I say to you, the cock will not crow before you deny me three times" (John 13.38).

The other meaning of following Jesus points to his return to the Father and the final destiny of all human beings. Jesus tells Peter, "where I go you cannot yet go." Jesus' announcement of his departure caused confusion among his disciples. Thus the succeeding passage (John 14) was an occasion to comfort his followers. Jesus clearly wanted to help his disciples overcome their confusion and therefore admonished them to be steadfast in their heart: "Do not let your hearts be troubled. You have faith in God; have faith also in me" (John 14.1). Jesus admonishes the disciples to believe in God. The only way they can know God is by knowing him, the one sent by the Father.

Jesus' use of the image of the Father's house with many dwelling places stresses the limitless love of God for all who come to him and he assures his disciples that he will prepare a restful place for them. The disciples must keep close to Jesus because he alone can take them there (John 14.2-3).

After the theme of dwelling places (John 14.3) the principal theme turns to "the way" (John 14.4). Jesus tells his disciples, "Where I am going you know the way" (John 14.4). This puzzling declaration of Jesus only increases the disciples' confusion. This becomes apparent when Thomas asked the Lord, "Master, we do not know where you are going. How can we know the way?" De la Potterie points out that the "question reveals his desire to know the way more than his ignorance of the place" (60). Jesus answered Thomas' question, "I am the way, the truth, and the life. No one comes to the Father except through me" (John 14.6).

The theme developed in John 14.2-6 is the place where Jesus is going and "the way" to it. According to De la Potterie, the entire passage seems to be inspired by Deuteronomy 1.29-33: 
Have no dread or fear of them. The Lord, your God, who goes before you, will himself fight for you, as he took your part before your very eyes in Egypt, as well as in the desert, where you saw how the Lord, your God, carried you, as a man carries his child, all along your journey until you arrive at this place. Despite this, you would not trust the Lord, your God, who journeys before you to find you a resting place-by day in the cloud, and by night in the fire to show you the way you must go.

The Lord God who journeys before His people finds their resting place and shows the way they must go. He Himself will fight for them. De la Potterie suggests that this important event in Exodus is applied to Jesus: "It applies typologically to Jesus the important outcome of the Exodus. Just as God puts himself at the head of his people to find a homeland for them to dwell in, so Jesus takes the lead for the new Exodus" (60).

However, Schnackenburg rejects this idea from Deuteronomy that describes God as putting Himself ahead of His people, and remarks that "The way is insufficiently explained by the Old Testament statement that God went ahead of the Israelites on their way through the desert in order to look for a camping place for them" (66). For Schnackenburg this idea may seem inadequate in explaining the function of Jesus as the one who manifests the Father.

Jesus as "the way" is illustrated in John's gospel, wherein Jesus alludes to himself as "the gate": "Whoever enters through me will be saved, and will come in and go out and find pasture" (John 10.9). This gate of salvation alludes to the Messianic understanding of Psalms 118.20 which states, "This is the gate of the Lord; the righteous shall enter through it." The gate is not for the shepherd but for the sheep: through it the sheep will reach pasture, whereupon it is safe and nourished. The sheep which enters through this gate belongs to Jesus. He is the gate to the pasture, that is, to life, so that those who enter through him will have life to the full.

This is a sentiment found in Jesus' farewell discourse, according to Michael Mullins (248-49). Anyone who enters by Jesus will have a full life or an abundant life. This fullness of life is beyond existing and breathing. It is a life characterized by natural exuberance, and more importantly by a particular quality of the interior or spiritual life.

John 14.6 forms a link with the preceding text (verses 2-5) and the succeeding text (verses 7-11). For the first half of the passage, verse 6 is to be interpreted in the sense that Jesus could take his disciples with him into the presence of the Father. He is "the way" in a strictly eschatological sense. However, after verse 6 the frame of time shifts from a future event to a present reality. 
John 14.7-11 presents "the way" as an event at hand. These verses illustrate three movements. First, Jesus Christ explains to his disciples that through knowing him they can come to know the Father: "If you know me, then you will also know my Father" (John 14.7a). Second, Philip failing to understand Jesus says, "Master, show us the Father, and that will be enough for us" (John 14.8). Jesus replied, "Have I been with you for so long a time and you still do not know me, Philip? Whoever has seen me has seen the Father. How can you say, 'Show us the Father'?" (John 14.9). Finally, Jesus explains that one can see the Father only through the Son who accomplishes his works. De la Potterie points out that the "knowledge of the Son leads to the knowledge of the Father because of the communion between the Father and Son; but to know the Father through the Son one must see Jesus with the eyes of faith, that is, one must discover the Son in him" (63). Jesus is "the way" to the Father because he is "the truth" or the revelation of the Father, since one can come to the knowledge of the Father only through Jesus who has seen and heard the Father. He manifested the intimate union between the Father and the Son. He is the only Begotten Son of the Father. Hence, to know and to see Jesus is to know and to see the Father. Jesus is "the way" because he is "the life" for he lives in the Father and the Father dwells in him, accomplishing His everything through him, and through him the life of the Father is given to believers.

John 14.7-11 illustrates that "the truth" and "the life" do not stress the eschatologically divine realities and the end to be attained but highlights the truth that Jesus is "the way." He is "the way" to the Father precisely in so far as he is "the truth" and "the life." Because he is "the truth" and "the life" Jesus alone can lead all to the Father.

\section{The Truth}

Jesus is "the way" because he is "the truth." The Jewish background of "the truth" in the Fourth Gospel is developed by De la Potterie, who states that

if one assumes the dualistic concept of truth as the background, it is easy to reach a view of revelation of a type associated with the mysteries of Gnosticism, which is hard to reconcile with the Incarnation of the Logos. If, on the other hand, one places John further, along the line of apocalyptic and wisdom tradition, one gives the important role of the Incarnate Logos and the Spirit in the transmission of truth its proper place. ${ }^{5}$

\footnotetext{
${ }^{5}$ Cited in Rudolf Schnackenburg "The Johannine Concept of Truth," in The Gospel
} 
Truth is to be understood in view of the apocalyptic and Wisdom tradition as the revelation of God's mystery and His divine plan of salvation.

Truth in the Old Testament is descriptive of God. He is the truth for He keeps His promises as He did to his servant David: "Lord God you are God and your words are truth; you have made this generous promise to your servant" (2 Sam. 7.28). "For the Lord's word is true; all his works are trustworthy" (Ps. 33.4). His ways are described as mercy and truth (Tob. 3.2b). Israel, God's people, is protected and redeemed through God's kindness and truth: "Withhold not, O Lord, your compassion from me; may your kindness and your truth ever preserve me" (Ps. 40.12b).

Those who trust in Him will gain the knowledge of God and of heavenly wisdom. "Those who trust in him shall understand truth" (Wisd. 3.9). The truth of God demands that one loves the truth and observes it, and does what is right by the truth. In Tobit's instructions to his son he said, "For if you are steadfast in your service, your good works will bring success, not only to you, but also to those who live uprightly" (Tob. 4.6).

God made a covenant with His people Israel. God's will and truth were revealed to His people in the form of the Law or the Torah: "You have been told, O man, what is good, and what the Lord requires of you; only to do right and to love goodness and to walk humbly with God" (Mic. 6.8). He commanded His people to keep their part of the covenant by observing the law faithfully.

God kept His part of the covenant He promised not only for Israel but for all people by sending His Son. All that God revealed in the Old Testament especially in the law given through Moses has been transcended and brought to fulfillment by the revelation of the Son who is "full of grace and truth" (John 1.18).

The Son, sent from above, speaks only the truth which he heard from God (John 8.40) and what he has seen in the Father's presence (John 8.38), for he is the only one who has seen the Father (John 1.18). He brought the truth from above, from the divine realm unattainable to man, down to earth, and reveals the truth in his very person, in his words and deeds and most fully on the cross. His words give expression to God's truth: "For the One whom God has sent speaks the words of God" (John 3.34). He is the truth for he embodies the divine truth, and bears witness to the truth: "The one coming from above has heavenly knowledge, and can witness to what he has seen and heard" (Mullins 149).

According to John (New York: Crossroad, 1982), 226. 
In proclaiming himself as "the truth," Jesus is not giving an ontological definition in terms of the transcendental but is describing himself in terms of his mission to men (Brown 630). His mission is to communicate the words of God, to be the Revealer of the Father: "I have much to say about you in condemnation. But the one who sent me is true, and what I heard from him I tell the world" (John 8.26). Jesus speaks of his own divine life and his life-giving mission. Jesus declares to the world what he heard and saw in the Father's presence.

\section{The Life}

He is "the way" because he is "the life." This is again a description of Jesus in terms of his mission to humanity: "I came that they may have life and have it to the full" (John 10.10). Jesus is the true source of life. "For just as the Father possesses life in himself, so also he gave to his Son the possession of life in himself" (John 5.26); the Son alone can give eternal life to those who believe in him (John 10.28).

The meaning of "life" in the Gospel of John can be uncovered by looking at its antithesis, death, as depicted in the fall of the man and woman in Genesis 3. Genesis 1 describes man and woman as the pinnacle of God's creation: "God created man in His image; in the divine image He created him, male and female He created them" (Gen. 1.26-27). Man and woman were given life, freedom and destiny which were "intended to be like God but in God's ways and with God's means" (Vawter 65). The Creator warned them that on the day they would disobey Him and eat the forbidden fruit they would die. But the serpent countered this assurance: "You will not die." It was this lie that woman and man believed. Since they disobeyed God's command and chose to become "like god" in their own way and in their own terms, God banished them from the Garden of Eden and forbade access to the tree of life. Death, the consequence of their disobedience, is the separation between humanity and God. Death in Genesis 3 also alludes to judgment, wrath, condemnation, hunger, thirst, darkness, lies and slavery.

God, however, did not abandon man and woman. In the same chapter, God promised redemption for them, through the second Adam, Jesus Christ: "I will put enmity between you and the woman, and between your offspring and hers; He will strike at your head while you strike at his heel" (Gen. 3.14-15). The enmity between Satan and the woman's descendant gives the first hint of a future Redeemer. The prophecy about the woman is fulfilled in the person of the Blessed Virgin Mary and her offspring, Jesus Christ, the Redeemer of the world. God's plan of redemption begins with 
creation, continues in his relations with his Chosen People and is fulfilled in Jesus Christ, the promised Redeemer. Through Jesus' life and redemptive Paschal act of suffering, death and resurrection he brings salvation to all humanity. As Jesus said, "Those who live in me ... will never die."

Christ is the life-giver sent by God who has come down from heaven and gives life to the world. As Rudolf Schnackenburg explains:

This life of God, which Christ embodies in his person, reveals and imparts in his words (John $6.63,68$ ) and manifests and symbolically transfers in his signs (healing, feeding, raising), is given to all who accept his revelation and believe in him. For them it means liberation from the realm of death (5.24) and breaking down of the barrier of death (8.51; $11.26 ; 12.25)$, not in a hope for the future but here in life now. (355)

The Incarnate Word gives meaning to human life, life in its essence. He is the way to life, the truth about life because he is life itself (Lussier 7). Jesus is "the way" because he is "the truth" and "the life." "Truth" and "life" are not simply coordinates. In the Gospel of John, the evangelist links truth with life to indicate the means by which Christ confers life. Life is bestowed always through belief in his words as the truth. Those who believe in Jesus as "the truth" or the incarnate revelation of the Father receive the gift of life, so that the words of Jesus are the source of life. "The man who hears my word and has faith in him who sent me possesses eternal life" (John 5.24). Jesus is the living water springing up to eternal life (John 4.14) and anyone who drinks this water will never thirst. The life of the Father is given to us in the truth revealed by Jesus. Through the truth we participate in the divine life: "The theological sense of the metaphor of the way is therefore clear-to go to the Father is to become, through the truth which is Christ, a sharer in the life of the Father" (De la Potterie 62).

\section{II. "I am the way, the truth and the life. No one comes to the Father except through me" (John 14.6)}

In most cases Jesus' "I am" sayings are followed by one nominal predicate; there are only two instances they are followed by more than one. The first is Jesus' answer to Martha, when he said, "I am the resurrection and the life." The second nominal predicate is joined to the first by kai ("and"). The second instance is in John 14.6, which is also the only text in which a third predicate is also linked by kai. Although the three terms are joined grammatically by the double kai, their sense is not as such. The first kai is simply explanatory. 
Brown explains that "[i]f the three phrases, 'the way,' 'the truth,' and 'the life' are joined by 'and' the 'kai' between the first and second may be epexegetical or explanatory (=that is to say)" (621). The abstract concept of "the way" which is used here as a metaphor for Jesus is at once clarified and strengthened by the two other predicates "the truth" and "the life." These additional words are embodied by Jesus Christ and therefore clarify who Jesus Christ is. Hence, the emphasis is placed entirely on the term "the way." Jesus is "the way" for he is "the truth" and "the life." "The truth" leads all to the Father. The meaning of Jesus' pronouncement is further clarified through an analysis of the verse's structure.

Verse 6 has two parts, one positive and the other negative. The first part, "I am the way, the truth and the life" presents the positive aspect of the verse and is the primary theme which presents Jesus as "the way." As noted above, Jesus is "the way" because he is "the truth" and "the life" and thus he is the perfect revealer of the Father.

The second part, "no one comes to the Father but through me" is the negative aspect of the verse which points to the secondary theme of the text. It refers to the end to be attained which is to know and see the Father and insists on the uniqueness and distinctiveness of "the way." No one can come to the Father but through Jesus Christ. This part has to be interpreted in the light of the preceding part. Thus, Jesus' self-revelatory statement is given a precise and absolute expression in the second part of the verse. He does not only lead the way to the Father or to the many rooms in the Father's house but he is the way which signifies his life-giving relationship with the community of believers (Mullins 319). Through him the invisible and incomprehensible God has made himself and his plan of salvation known so that all are able to reach the meaning of their existence through their interpersonal loving relationship. This is possible in the acceptance of faith and truth that has been revealed in Jesus Christ and in the sharing in Jesus' faith, hope and love.

From the analysis of the positive and negative parts of verse 6 it is clear that the principal element is the first term, "the way." The other two terms, "the truth" and "the life" explain the metaphor. The second part of the verse contains the end to be attained. Jesus is the way because the ways of God are truth and love: "All the paths of the Lord are faithful love" (Ps. 25.10). He reveals the thoughts and ways of God that are beyond the human mind, as the heavens are past the earth: "For my thoughts are not your thoughts, nor, are your ways my ways, says the Lord" (Isa. 55.8).

Jesus' mission as seen in his saving death is to draw all to himself and to gather together the believing community. Therefore, Jesus' claim to be "the 
way" is not merely an eschatological promise that points to future reality. He is the way because he is the revealer and the revelation of God. The truth is the revealed reality of God's involvement in human history that manifests His love for His people. The life is the divine life which is bestowed to those who have faith in Him. In his farewell discourse Jesus prayed to the Father and said, "Now this is eternal life, that they should know you, the only true God, and the one whom you sent, Jesus Christ" (John 17.3).

\section{III. "I am the way, the truth and the life" in light of the Prologue}

Another way to explain John 14.6 is to compare it with parallel verses in the Prologue, specifically verses 1, 14 and 18.

The first verse of the Prologue states that "In the beginning was the Word, and the Word was with God, and the Word was God" (John 1.1). The beginning of John's Gospel already proclaims the preexistence of the Word. The Word is present in the divine eternity. The eternal divine Word existed before creation. Uncreated, the Word was in God's presence. The Word was God.

The Word from all eternity became flesh and made his dwelling among us: "And the Word became flesh" (John 1.14). Ruth Edwards comments that "[i]n these simple words the whole profound mystery and miracle of the Christian faith is expressed" (91). The mystery of the Incarnation grounds a new mode of existence of the Word. The Word and the only begotten Son, one with the Father, enters human history. The Word empties himself and expresses himself in a complete human existence. John O'Grady adds that " $[\mathrm{t}] \mathrm{he}$ abstract Word of God becomes concrete in Jesus; a communion of being and loving between God and Jesus reveals both God and the intimate relationship that exists between God and humanity" (162). The humanity of the Word is the new localization of the presence and glory of God on earth. Jesus is the expression of the Word and the definitive revelation. Thus, the words and deeds of Jesus are words and deeds of the divine. This is why Jesus can claim that "Whoever has seen me has seen the Father" (John 14.9).

John 1.18 states that "No one has ever seen God. The only Son, God, who is at the Father's side has revealed him." This emphasizes the full divine dignity of the Son who is in the bosom of the Father, who became man, making him the unique revealer of the Father. No one has ever seen God. The only Son of the Father, ever at the Father's side, makes known the Father. Jesus is the unsurpassable and definitive revelation because he is the Word Incarnate, the only begotten Son of the Father who is in the bo- 
som of the Father. Ruth Edwards stresses that "Jesus is able to 'explain' or 'reveal' the Father because he has uniquely seen and known him" (94).

There are two theological themes expressed in these texts. First, there is a clear distinction between the Father and the Son, the Son being presented not only as being in the Father but as being related to the Father, not identified with him. Secondly, the Father is the begetter and the Son is the only begotten One of the Father. The relation between the Father and the Son is essentially filial.

The divine revelation takes flesh in the very person of Jesus Christ. The act of revealing for Christ consists essentially in revealing himself. According to De la Potterie, "[t]o know truth is to penetrate the mystery of Jesus and to find in him the Son of the Father. When Jesus reveals his glory to us, he makes us existentially take part in the mystery of the life of the Son and the Father. It is this revelation that becomes for us the truth" (63). Schnackenburg states that when John uses the phrase "the Son," his intention is to express Jesus' moral unity with God-his utter obedience to God, his one will with God's, his authority from God, his speaking God's words, his doing God's work including tasks of life-giving and judgment and his sharing in God's glory (172-86).

The three terms-"the way, the truth and the life"-describe at once a descending and an ascending movement. The descending movement is from the Father to all people, and is fulfilled in the Incarnation through the revelation to us of Christ who is "the truth." Jesus, the Incarnate Word, reveals the truth about his divine life and offers to give this life to those who believe in him. The ascending movement is from all people to the Father, and it passes through Christ who is "the way." Jesus is the only way to the Father since he alone is at the same time flesh among all people and the Word with the Father.

The scriptural analysis of John's Prologue verses 1, 14 and 18 and their relation to John 14.6 again highlights the primary term in John 14.6, which is "the way." As Schnackenburg explains:

As 'truth' Jesus is the mediator between the Father and men in the order of knowledge (descending movement). But as 'way' he mediates in the order of communion of life (ascending movement). The first mediation is subordinate to the second because truth is ordained for life: Jesus is the truth in order to give life. (64)

Therefore the primary term of the verse is "the way" because Jesus shows the way to the Father. "The truth" and "the life" are explanations of "the way." Jesus is "the way" because he is "the truth" and gives people the con- 
solation of the truth so that all may come to know and see the Father. He is "the way" because he is the Good Shepherd who leads all to the everlasting life since he lives in the Father and the Father lives in him, and through him the life of the Father is given to all those who believe in him.

\section{Theological Significance of Jesus as "the way, the truth and the life."}

The religious faith of Filipino Catholics in Jesus Christ as the way, the truth and the life has always found expression in various forms of piety (CCC 1674). Popular piety, expressed in the veneration of relics, processions, pilgrimages, and devotions, is a genuine inculturation of the faith (LG 67). Filipino Catholics persevere in their faith in Jesus Christ through the rich and popular religious traditions, such as the simbanggabi, various processions, and many other practices that nourish their faith.

The gospels illustrate Jesus Christ as "on the way" or on the road. The repeated actions build up the impression of a movement or a journey and pilgrimage. Jesus was on the way from Galilee to Jerusalem. It was a long journey that has its final destination not only the cross, but also the glory of Easter and the Ascension (Luke 9.51; 24.1-52). In Jesus' journeys he was always portrayed as going ahead of his disciples. "Going before" can refer to someone's relative position in a journey in terms of time and location, but in its biblical sense symbolizes Jesus' personal relationship with his disciples. As their leader, Jesus goes before his disciples to reveal to them that he is the truth and the source of life and instructs them to follow him.

His disciples followed him wherever he went. But following Jesus was not simply an external act, or a walking behind him. The disciples had to undergo an interior conversion and change in their way of life. As they heard Jesus' call the disciples immediately dropped their nets and became Jesus' companion. Their life was centered no longer in their livelihood but on Christ himself and on their participation in his mission.

The religious procession, a popular devotion, is a symbolic representation of the disciples' "following Christ." It is first and foremost a joyful witness and commitment to Jesus Christ. The procession is the disciples' expression of "yes" to Jesus and their willingness to go with him wherever he leads them.

The procession of the Black Nazarene has a long-standing tradition that dates back to the $17^{\text {th }}$ century. It is the Philippines' best-known and most-attended religious practice. This devotion is actually rooted in the gospel narratives, where Jesus was closely followed by his mother Mary and some of his disciples on his way to Calvary. 
The statue of the Black Nazarene is housed in the St. John the Baptist Church, which is the Minor Basilica in Quiapo, Manila; his feast day is celebrated every $9^{\text {th }}$ of January. The devotees of the Black Nazarene are from all walks of life, and are mostly men. They shout "Viva Señor" as soon as the doors of the Church open for the image to exit. The barefooted devotees follow the image of the Black Nazarene that is placed on a carriage that goes around the district of Quiapo the whole day until the image returns to the basilica at the end of the procession. The devotees reach out to touch the image so as to have an encounter with the divine. This encounter is likened to the meeting of heaven and earth depicted in some of the gospels' healing narratives (Mark 4.41). However, this practice can be abused and may lead to fanaticism, such as when people jostle and hurt one another just to touch the image.

The Black Nazarene is an image of the suffering Son of Man as he rises from a fall brought about by the weight of the cross he carried on his shoulder as he journeys to Calvary where he would give himself up to death. This image of the Black Nazarene is perhaps what draws the devotees. They identify their daily struggles and difficulties in their lives with the pain and suffering endured by Jesus Christ. Jesus' getting up from the fall and his triumph in the resurrection where he destroyed death and restored life serves as the symbol of hope for the faithful devotees. The Filipino devotees believe that their participation in the procession of the Black Nazarene is a sign of their sharing in Jesus' paschal mystery because in him and through him they have found life. Other devotees who join the procession believe that this religious practice is for the reparation of their sins and conversion. There are devotees who join the procession to ask for divine assistance or to give gratitude for blessings received.

While the procession is an external act of walking behind and following the image of Jesus Christ, it must also involve the interior dimension which is the constant conversion and maturing in faith. This means that the devotees of the Black Nazarene and of other religious practices must realize that any devotion demands an interiority wherein the faithful realize that the teaching of Jesus demands following him: not simply to walk behind him, but to walk after him as his true disciple. Jesus instructs his disciples, "Whoever wishes to come after me must deny himself, take up his cross, and follow me" (Matt. 16.24). By following Jesus, the disciples must enter into the service of truth and love. This requires an interior transformation from self-centeredness and individualistic fulfillment to continuous growth in love for others, understood as the reason for living. "For whoever wishes to save his life will lose it, but whoever loses his life for my sake and the gospel will save it" (Mark 8.35). 
Jesus reveals the true meaning of authentic love in the washing of the disciples' feet (John 13.1-20). At the beginning of the account Jesus highlights his love for his disciples to the end. This is a love that is beyond time which can only come from God. Jesus becomes a servant and washes the disciples' feet, a symbol of the disciples' weary bodies and forlorn spirits. Jesus pours himself out to his tired followers to uplift and strengthen them.

The Washing of the Feet that comes before the passion narrative foreshadows Jesus' self-emptying love on the cross. Jesus lays down his life for his followers; his self-sacrifice becomes the norm of discipleship. Love takes a new meaning; Jesus instructs his disciples that in the way that they have received divine love so must they love one another: "You ought to wash each other's feet" (John 13.14).

In his farewell address during the last supper with his disciples Jesus gives them a new covenant. As he manifested the divine love for his disciples, thus must they love one another. The new commandment is new because the basis of this love is Christ's own love: "as I have loved you, so you also love one another" (John 13.34).

Jesus revealed that God is love. Paul Wadell explains that "Jesus presented himself as the rule or measure of love. In his teachings, in his attitudes and actions, in the shape of his entire life, Jesus was the perfect expression of divine love" (200). Jesus calls his disciples to conform their lives to the love of God that is manifested in him. Jesus, God's love incarnate, becomes the new norm for living and loving. Paul Wadell's words can serve as summary: "No longer is our love for our neighbor to be measured by the love we have for ourselves. Rather, the measure of our love for others is to be the love we have received from God. The norm for loving shifts from self-love to God's love for us as revealed in and by Christ" (200).

\section{WORKS CITED}

Brodie, Thomas. The Gospel According to John. New York: Oxford UP, 1993. Print.

Brown, Raymond. The Gospel According to John, XIII-XXI. New York: Doubleday, 1970. Print.

"Dei Verbum (DV)" 22 in Vatican Council II: The Conciliar \& Post Conciliar Documents. Ed. A. Flannery (1975).

De la Potterie, Ignatius. "I am the way, the truth and the life." Theology Digest 16 (1968): 59-64. Print.

Edwards, Ruth. Discovering John. London: SPCK, 2003. Print.

Episcopal Commission on Catechesis and Catholic Education. Catechism of the Catholic Church (CCC) 1674 (Manila: Word \& Life, 1997). 
Forestell, J. Terence. The Word of the Cross: Salvation as Revelation in the Fourth Gospel. Rome: Biblical Institute, 1974. Print.

"Lumen Gentium (LG)" 67 in Vatican Council II: The Conciliar \& Post Conciliar Documents. Ed. A. Flannery (1975).

Lussier, Ernest. Christ's Farewell Discourse. New York: Alba House, 1979. Print.

Marrow, Stanley. The Gospel of John: A Reading. Manila: St. Paul's, 1995. Print.

Minear, Paul S. "The Promise of Life in the Gospel of John." Theology Today 49 (January 1993): 485-99. Print.

Mullins, Michael. The Gospel of John. Dublin: Columba, 2003. Print.

O'Grady, John. "Jesus the Revelation of God in the Fourth Gospel." Biblical Theology Bulletin 25 (Winter 1995): 161-65. Print.

Raas, Bernhard. Popular Devotions. Manila: Divine Word, 1992. Print.

Schnackenburg, Rudolf. The Gospel According to St. John. New York: Crossroad, 1982. Print.

Vawter, Bruce. A Path Through Genesis. New York: Sheed, 1956. Print.

Wadell, Paul. Happiness and the Christian Moral Life. Lanham, MD: Rowan, 2008. Print.

Maria Lucia C. Natividad, an Associate Professor of the Theology Department of the Ateneo de Manila University, teaches an introductory theology course to undergraduates and is also a Lecturer at the Loyola School of Theology. She was the former Director of the Formation Institute for Religion Educators (FIRE Program), which is the graduate program of the Theology Department. 